\title{
KAJIAN GAYA VISUAL STORYTELLING TATANG SUHENRA
}

\author{
Gun Gun Gunawan ${ }^{1}$, Alvanov Z. Mansoor ${ }^{2}$ dan Naomi Haswanto ${ }^{3}$ \\ 1,2,3 Institut Teknologi Bandung
}

\begin{abstract}
Abstrak: Tatang Suhenra adalah salah seorang komikus legendaris Indonesia yang terkenal dengan karya komiknya berupa komik silat, komik cerita Punakawan, dan komik religius. Komik-komik karya Tatang Suhenra menjadi benda koleksi yang bernilai tinggi karena dapat terus dikonsumsi saat komik Indonesia sulit bersaing pada periode 1980-an menjadi daya tarik utama yang menarik untuk dikaji lebih dalam. Aspek visual story telling komik Tatang Suhenra dikaji menggunakan teori Scott McCloud. Adapun hasil penelitian ini mengerucut pada pemanfaatan konten dan konteks lokal secara kreatif dari target pembacanya sebagai salah satu ciri kekhasan karya Tatang Suhenra selain pemilihan tokoh serta penokohan yang teliti dan konsisten. Hasil penelitian ini dapat digunakan sebagai acuan pembuat komik untuk mengatasi persaingan komik Indonesia dengan komik mancanegara
\end{abstract}

Kata kunci: Analisis teks, Komik, Komikus, Indonesia, visual storytelling.

\begin{abstract}
Tatang Suhenra is one of Indonesian comic artists who published various themes such as martial arts comics, Punakawan comics, and religious comics. His works become valuable collection items because they still continue to be found during 1980's, when Indonesia was difficult to compete in such creativity. This case is interesting to be examined in detail. Furthermore, the visual story aspect of this Tatang Suhenra's comic is observed by using Scott MsCloud theory. This study will depict the visual storytelling style of Tatang Suhenra through text analysis towards observation of his published artworks and literature study. By analyzing his artworks, we find that Tatang Suhenra elaborates creatively local content and local context of his readers' world besides carefully designs the characters and characterization. The results of this study can be used as a reference for making Indonesian comic to tackle comic competition in global world.
\end{abstract}

Keywords: Comic, Comic Artist, Creative Process, Framing Analysis, Visual Storytelling

Penulis utama adalah mahasiswa dan dosen jurusan Program Studi Desain Komunikasi Visual, Fakultas Seni Rupa dan Desain, Institut Teknologi Bandung, email: nova.zp@gmail.com 


\section{PENDAHULUAN}

Tatang Suhenra, yang lebih dikenal dengan nama pena Tatang S. dalam karya-karyanya, merupakan seorang komikus asal Bandung yang berkarir sejak tahun 1960 hingga tahun 1990 (Vertikal Digital Indonesia, 2011). Tatang dikenal sebagai komikus cerita-cerita silat yang populer sekitar tahun 1960-1970, pun Tatang Suhenra juga dikenal sebagai komikus yang mengangkat tokoh punakawan (Gareng dan Petruk) sebagai tokoh utama dalam komik yang bercerita tentang keseharian, romantika, serta horor yang dikemas secara jenaka. Selain itu, Tatang Suhenra juga dikenal sebagai komikus bertema religi (komik surga dan neraka) yang populer sekitar periode awal 1990-an.
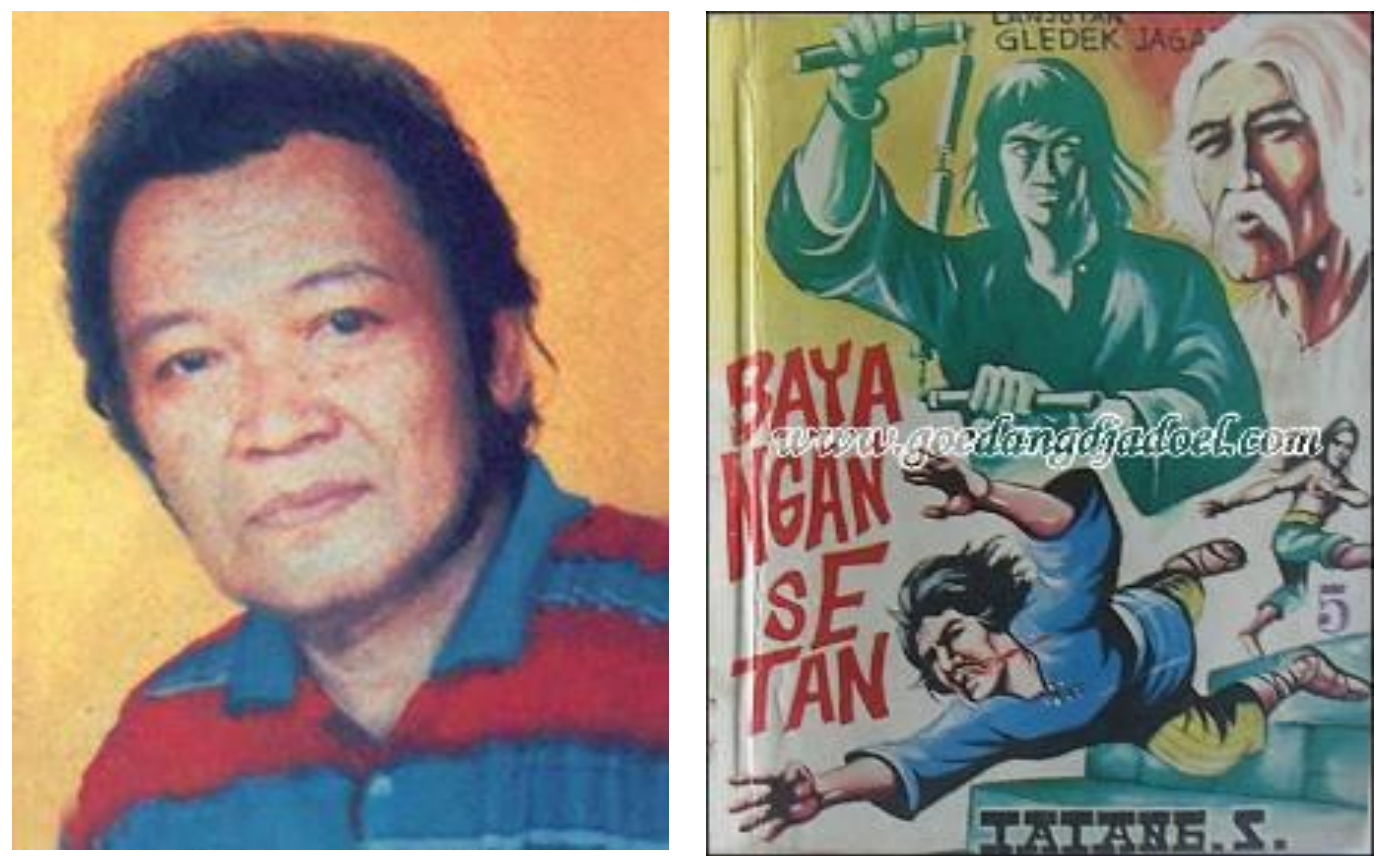

Gambar 1 Foto Profil Tatang Suhenra (kiri), dan salah satu Komik Silat karyanya (kanan) Sumber: Sekedar Info, 2010 (kiri), Permana, 2012 (kanan).

Tatang Suhenra pada periode akhir 1970-an tidak dapat melanjutkan karirnya sebagai komikus cerita silat karena terseret dalam konflik antara penerbit tempatnya bernaung dengan komikus silat sebelumnya. Setelah karir sebagai komikus silat berakhir, Tatang Suhenra muncul kembali pada tahun 1980 
ketika industri komik Indonesia dibanjiri komik asing terjemahan dari Eropa, Amerika, dan Jepang yang menyebabkan komik lokal sulit untuk berkembang ( $\mathrm{Al}$ Amin, 2015). Tatang Suhenra berkarya melalui komik bertema keseharian masyarakat yang dikemas dengan jenaka, yakni komik Gareng Petruk. Komik ini berisi cerita-cerita keseharian Gareng dan Petruk di sebuah desa bernama Tumaritis yang selalu bertindak ceroboh, kocak, dan kadang ngawur.

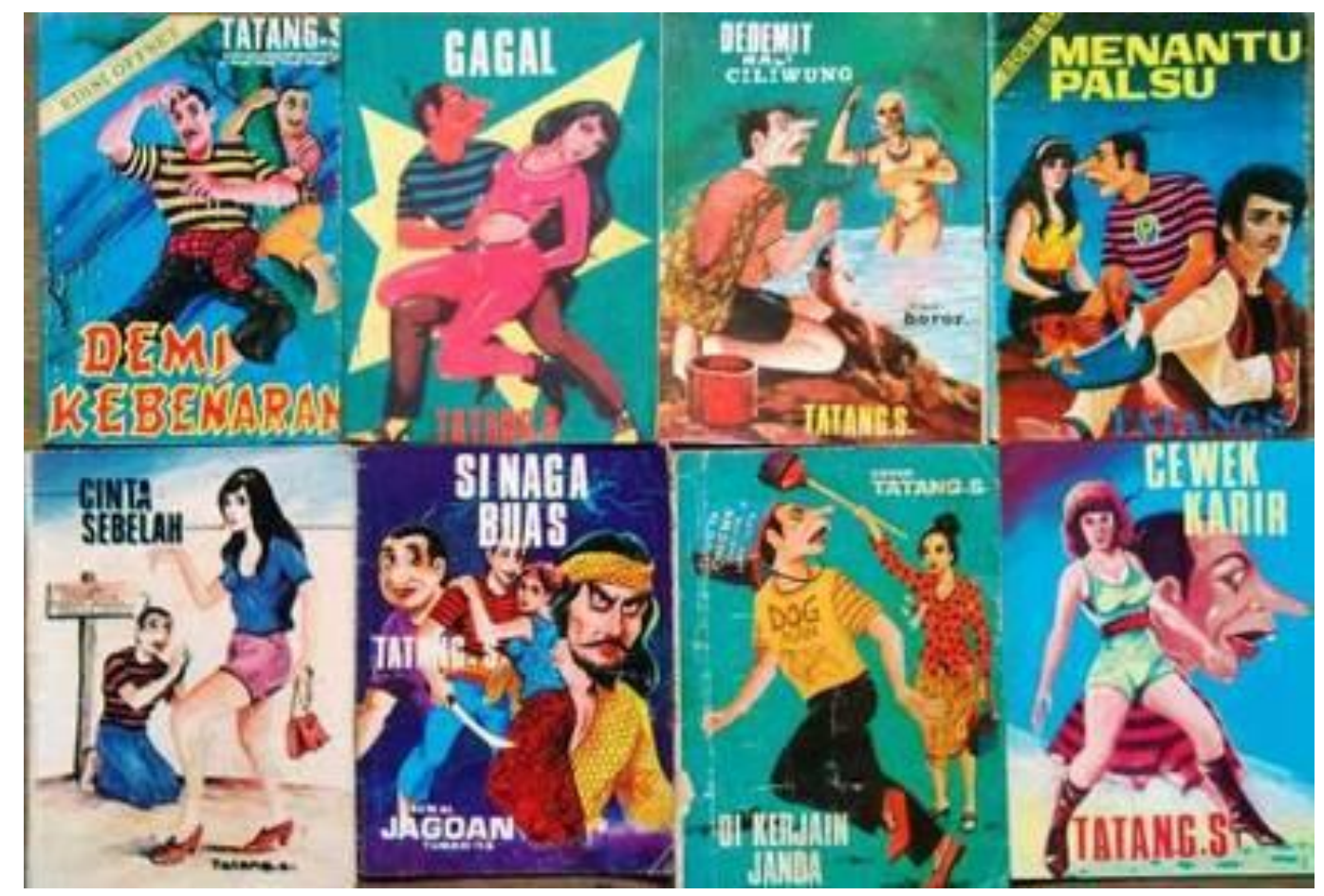

Gambar 2 Komik Gareng Petruk karya Tatang Suhenra Sumber: Psikomedia, 2013

Selain tema horor, kisah Gareng Petruk juga sering mengangkat tema superhero, seperti kisah Petruk yang menjadi Superman, Robocop, Megaloman; juga kisah roman keseharian yang dibawakan dengan tema humor (Sekedar Info, 2010). Komik karya Tatang Suhenra selalu ditargetkan untuk kalangan menengah ke bawah, serta jalur distribusi komik yang mengandalkan pasar asongan dan pedagang mainan di sekolah-sekolah dasar, pada saat itu kurang tersentuh oleh pasar utama komik. Memasuki era 1990, Tatang Suhenra kemudian menggarap 
komik dengan tema religi dan populer terutama di kalangan anak-anak SD tahun 1990 hingga tahun 2000-an.

Tatang Suhenra dapat terus berkarya dengan beragam karya komiknya, khususnya melalui komik yang mengangkat tokoh punakawan selama periode 1980-an dalam industri komik Indonesia adalah sebuah prestasi yang signifikan. Terutama jika merunut pada kondisi industri saat itu, pasar komik Indonesia dipenuhi oleh komik terjemahan asing dari Amerika, Eropa, dan Jepang, komik karya Tatang Suhenra tetap memiliki pasar pembacanya. Oleh karena itu, baik untuk dikaji keunikan dan kekhasan yang diangkat oleh Tatang Suhenra dalam karyanya sehingga tetap dapat bersaing dengan komik-komik terjemahan asing tersebut, khususnya dalam hal gaya penceritaan visual (visual storytelling).

Dalam hal ini, gaya visualisasi cerita atau visual storytelling Tatang Suhenra dalam menyampaikan cerita melalui komiknya pada periode 1980-an menarik untuk dikaji. Bagaimana pengolahan cerita dengan cara tertentu dapat menjadi kekuatan dan daya saing bagi seorang komikus.

\section{KAJIAN TEORI}

Komik dalam dunia desain komunikasi visual, berfungsi sebagai salah satu media penyampaian ide/ gagasan /informasi kepada masyarakat melalui cerita yang divisualisasikan dengan gaya penceritaan visual (visual storytelling) tertentu dalam rangkaian gambar. Akan tetapi komik sebagai media, tetap disusun atas sejumlah elemen berdasarkan prinsip penceritaan visual.

\section{Komik dan Unsur Intrinsik Komik}

Menurut Will Eisner dalam McCloud (1993: 5-7), komik adalah sequential art atau seni yang berurutan. Gambar-gambar jika berdiri sendiri dan dilihat satu persatu tetaplah hanya sebuah gambar, akan tetapi ketika gambar tersebut disusun secara berurutan, meskipun hanya terdiri dari dua gambar, seni dalam 
gambar tersebut berubah nilainya menjadi seni komik. Menurut McCloud (1993), pengertian komik ini masih terlalu umum, kata Sequential Art juga bisa dipakai untuk animasi, mengingat animasi juga merupakan rangkaian dari gambar atau seni yang berurutan dan menjadi satu kesatuan utuh. McCloud (1993) menggarisbawahi perbedaan mendasar antara komik dan animasi adalah bahwa rangkaian animasi berurutan oleh waktu, sedangkan komik dipisahkan oleh panel yang tersusun saling berdampingan (jukstaposisi). Oleh sebab itu, McCloud (1993) mendefinisikan komik gambar dan lambang yang terjukstaposisi atau saling berdampingan dalam urutan tertentu yang bertujuan untuk menyampaikan informasi dan atau mencapai tanggapan estetis dari pembacanya.

Adapun gambar atau lambang yang disusun tersebut merupakan komposisi dari berbagai elemen intrinsik yang membentuk komik. Menurut Nurgiyantoro (2011), unsur intrinsik dalam komik dirincikan sebagai berikut:

\section{a. Cerita}

Selain unsur visual, cerita menjadi bagian penting dalam komik. Forster dalam Nurgiyantoro (2011: 91) mengartikan cerita sebagai sebuah narasi berbagai kejadian yang sengaja diurut berdasar waktu. Menurut Eisner (1996: 23-41), berbagai ungkapan cerita dapat disampaikan dalam sebuah media grafis (gambar) dapat berupa Stories to Instruct (cerita yang berisi intruksi atau petunjuk), a How-to Story (cerita yang mengajarkan tentang sesuatu), The Plotless Story (plot yang sangat sederhana, hanya memunculkan satu permasalahan saja), The Illustrated Story (cerita yang merupakan lukisan kejadian dari sebuah cerita), The Symbolistic Story (cerita yang mewakili sesuatu-simbol), The Slice of Life Story (cerita yang mengungkapkan potongan cerita sebuah kehidupan), dan $A$ Life Story (cerita tentang kehidupan seseorang). 


\section{b. Plot (Alur Cerita)}

Stanton dalam Nurgiyantoro (2011: 113) menjelaskan bahwa plot merupakan cerita yang berisi urutan kejadian, tetapi dari setiap kejadian dihubungkan secara sebab akibat, yakni peristiwa yang satu mengakibatkan peristiwa yang lain. Terdapat 5 tahapan plot menurut Tasrif dalam Nurgiantoro (2011: 149), yaitu: pertama, tahap situation yang berisi pelukisan mengenai pengenalan situasi latar dan tokoh-tokoh cerita. Kedua, tahap generating circumstances yaitu tahap pemunculan konflik, masalah-masalah dan peristiwa-peritiwa yang menyulut terjadinya konflik mulai dimunculkan. Ketiga, tahap rising action yaitu tahap peningkatan konflik, pada tahap ini konflik yang telah dimunculkan berkembang dan dikembangkan kadar intensitasnya. Kemudian keempat, tahap climax/ klimaks, konflik dan atau pertentangan-pertentangan yang terjadi, yang dilalui dan atau ditimpakan kepada tokoh cerita mencapai titik intensitas puncak. Plot diakhiri dengan tahap kelima denouement yakni tahap penyelesaian; konflik yang telah mencapai klimaks diberi penyelesaian, ketengangan dikendorkan. Adapun terdapat pembedaan plot yang dapat dikategorikan dalam 4 jenis, diantaranya :

1. Pembedaan plot berdasar pada kriteria urutan waktu dan terdapat tiga jenis plot yakni kronologis (plot lurus-progresif), tak kronologis (plot sorot balik-flashback) serta plot campuran.

2. Pembedaan plot berdasar kriteria jumlah cerita yang terdapat dalam karya fiksi, terdapat 2 jenis plot yakni plot tunggal dan plot sub-plot.

3. Pembedaan plot berdasar kriteria kepadatan, yaitu padat tidaknya pengembangan cerita pada sebuah karya fiksi; terdapat dua jenis plot yakni plot padat dan plot longgar.

4. Pembedaan plot berdasar kriteria isi maksudnya adalah sebagai suatu kecenderungan masalah yang diungkapkan dalam cerita. 


\section{c. Penokohan}

Tokoh dan penokohan dalam peran tokoh utama serta pendukung antagonis dan protagonis dalam sebuah karya fiksi menjadi hal yang tak terelakkan, tokoh menjadi pelaku yang melakukan sesuatu dan menjadi bagian dalam cerita dan plot. Penokohan atau karakterisasi sering disamakan artinya dengan karakter dan perwatakan.

\section{d. Tema}

Pengertian tema menurut Stanton dan Kenny dalam Nurgiantoro (2011: 67) adalah makna yang terkandung dalam sebuah cerita. Nurgiantoro (2011) menambahkan bahwa tema dapat dipandang sebagai dasar cerita, dan gagasan dasar umum sebuah karya fiksi. Penggolongan tema didasarkan pada sudut pandang diantaranya:

\section{Tema tradisional dan non tradisional}

Tema tradisional merujuk pada tema yang stereotype dan dapat ditemukan dalam berbagai cerita, seperti: kebenaran dan keadilan mengalahkan kejahatan, kejahatan yang ditutupi akan terbongkar juga, kebenaran dan kejahatan akan memetik hasilnya, cinta sejati yang menuntut pengorbanan, kawan sejati adalah kawan di masa duka, dan lain lain. Sedangkan tema non tradisional merujuk pada cerita-cerita yang melawan arus, mengangkat sesuatu yang tidak lazim, dan mungkin tidak sesuai dengan harapan pembaca.

\section{Tema menurut tingkat pengalaman jiwa}

Tema menurut tingkat pengalaman jiwa diantaranya sebagai berikut:

a) Tema tingkat fisik, tema ini mengandung cerita pada aktivitas fisik dan kejiwaan.

b) Tema tingkat organik, tema ini banyak menyangkut dan atau mempermasalahkan soal seksualitas. 
c) Tema tingkat sosial, kehidupan bermasyarakat, sebagai tempat interaksi yang mengandung banyak permasalahan.

d) Tema tingkat egoik, yang mengangkat masalah individualitas, menunjukan jati diri, citra diri, martabat atau kepribadian.

e) Tema tingkat tinggi (divine) masalah yang diangkat adalah masalah hubungan manusia dan sang Pencipta.

\section{e. Latar}

Latar atau setting menurut Abram dalam Nurgiantoro (2011: 67) merujuk pada pengertian tempat, hubungan waktu dan lingkungan sosial tempat terjadinya peristiwa yang diceritakan. Unsur latar diantaranya:

a) Latar tempat, lokasi terjadinya peristiwa yang diceritakan dalam sebuah karya fiksi unsur yang mempengaruhi alur dan penokohan.

b) Latar waktu, berhubungan dengan masalah kapan terjadinya peristiwa yang diceritakan dalam sebuah karya fiksi.

c) Latar sosial menyarankan pada hal-hal yang berhubungan dengan perilaku kehidupan sosial masyarakat.

\section{f. Sudut pandang penceritaan}

Sudut atau point of view pada hakikatnya mempersoalkan siapa yang menceritakan atau dari posisi mana (siapa) sebuah peristiwa dan tindakan dilihat. Sudut pandang dibagi menjadi menjadi dua macam yakni persona pertama "aku" biasanya memerankan dan menyampaikan berbagai hal yang dimaksudkan pengarang. Persona ketiga "dia", yakni narator adalah seseorang yang berada diluar tokoh menampilkan tokoh-tokoh cerita, menyebut nama atau kata gantinya: ia, dia, mereka.

\section{Penceritaan Visual (visual storytelling)}

McCloud (2005) mengungkapkan bahwa visual storytelling pada akhirnya memiliki tujuan utama agar pembaca komik dapat mengerti dengan jelas cerita 
yang disampaikan dan juga mengajak pembaca untuk tetap mengikuti ceritanya. Visual storytelling pada komik dibagi menjadi beberapa rangkaian pengambilan keputusan, yaitu:

1. Pemilihan momen, yang berkaitan dengan bagaimana peralihan dari satu panel kepada panel lainnya. Pemilihan momen yang ingin ditampilkan serta momen yang harus dibuang, ditambah dengan pemilihan transisi panel yang baik, penambahan panel demi penekanan, pengaturan intensitas cerita serta efisiensi panel.

2. Pemilihan bingkai (frame), yang menentukan dari sudut pandang apa gambar ditampilkan dan seberapa besar proporsi tokoh atau objek dengan latar belakangnya. Pemilihan frame ini bertujuan untuk membuat pembaca dapat melihat tempat aksi berlangsung dan mungkin membangkitkan kesan berada di tempat kejadian. Proses ini ditentukan oleh faktor-faktor komposisi seperti cropping (tata pandang), balance (keseimbangan), dan tilt (kemiringan), yang mempengaruhi tanggapan pembaca terhadap dunia di dalam komik serta posisi mereka di sana.

3. Pemilihan citra (image yang ditampilkan), yang menentukan bagaimana tokoh, objek, dan suasana tersebut ditampilkan. Pemilihan image dapat bergantung pada gaya gambar seseorang, seperti realis, kartun, manga, dan sebagainya. Selain dari gaya gambar, Image yang ditampilkan pun berasal dari pemilihan karakter, sifat, latar belakang cerita, serta cerita itu sendiri.

\section{Pemilihan kata}

Pemilihan kata dalam komik dapat diklasifikasikan menjadi beberapa kategori berdasarkan fungsinya, di antaranya:

a) Kata menjadi narasi untuk menjelaskan cerita,

b) Kata dapat berperan maksimal sebagai dialog atau percakapan, yang diwujudkan dalam balon kata, dan sebagainya, 
c) Kata juga dapat mengambil fungsi sebagai sound effect (efek suara) untuk membuat pembaca "mendengar" bunyi yang terjadi dalam komik,

d) Kata dapat menjadi bagian langsung dari gambar sebagai bentuk terintegrasi. Contohnya adalah penggunaaan kata dalam gambar rumah makan atau gapura desa, dan lain-lain.

\section{Pemilihan alur (flow)}

Pemilihan alur sangat erat kaitannya dengan tata panel. Tujuan utama dari pemilihan alur adalah untuk menuntun pembaca mengikuti jalan cerita komik dari awal sampai ahir. Dalam komik, alur baca yang baik ditentukan oleh pengaturan panel ke panel yang tepat, baik itu penempatan panel maupun jarak antar panel.

\section{METODE PENELITIAN}

Penelitian ini merupakan penelitian kualitatif deskriptif eksplanatif, yaitu penelitian berupa kajian pada aspek-aspek non teknis atau tak terukur secara matematis yang menjelaskan relasi antara gaya visual storytelling dengan kerangka berpikir serta paradigma yang mendasari penerbitan karya Tatang Suhenra pada tahun 1980-an. Adapun pengumpulan data yang dilakukan adalah observasi, studi literatur, dan wawancara. Analisis menggunakan analisis framing untuk mengungkapkan kerangka berpikir serta paradigma Tatang Suhenra melalui aspek-aspek intrinsik komik serta tata ungkap penceritaan vsual.

\section{HASIL DAN DISKUSI}

\section{Unsur Intrinsik Komik Karya Tatang Suhenra}

\section{a. Tokoh dan Penokohan}


Komik karya Tatang Suhenra adalah komik yang berisikan cerita keseharian tokoh-tokoh punakawan yakni Gareng, Petruk, Bagong, dan Semar. Pada dasarnya komik ini memiliki nilai-nilai penting yang menjadikannya dekat dan populer di kalangan masyarakat lintas generasi. Cerita yang diangkat dalam komik ini mewakili realita keseharian masyarakat pinggiran yang memiliki cita-cita serta segudang masalah, seperti cerita Petruk yang ingin menikahi pacarnya namun terkendala masalah biaya sehingga tidak direstui oleh ayah sang pacar.
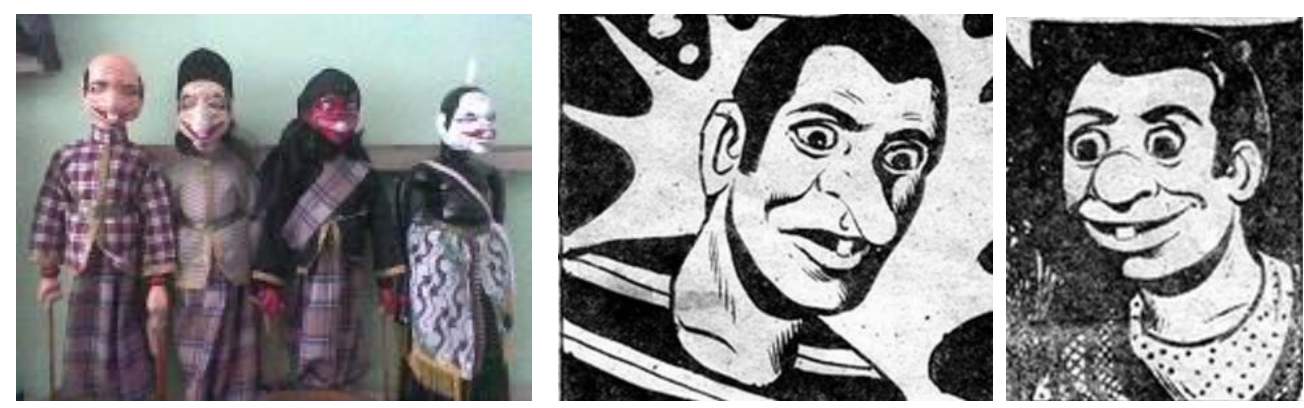

Gambar 3. Punakawan dalam wayang golek (kiri), Petruk dan Gareng karya Tatang Suhenra (tengah dan kanan)

Sumber: Sanggar Yudistira (kiri); Suhenra, 1986 (tengah \& kanan)

Punakawan pada dasarnya adalah tokoh-tokoh figuran yang berperan mencairkan suasana dengan lontaran humor ketika suasana cerita dalam wayang sedang berada pada suasana serius (misalnya perang), sehingga penonton dapat kembali nyaman dan tidak terlalu tegang. Namun, Tatang Suhenra justru membawa tokoh-tokoh figuran ini menjadi tokoh utama dengan "panggungnya" sendiri. Mereka menjadi cerminan masyarakat pinggiran kota dengan segala masalah dalam hidupnya.

Gareng, Petruk dan Bagong seringkali digambarkan sebagai tokoh pengangguran, banyak hutang, usil dan nekat. Dalam ceritanya, selalu digambarkan menemui berbagai kesialan dan persoalan hidup, angan-angan akan kekayaan dan wanita cantik. Adapun tokoh Semar berperan sebagai 
penengah masalah dan sebagai tetua yang sering memberi nasihat tentang kehidupan (nasihat ini biasanya berada pada halaman akhir cerita).

Tokoh dan cerita yang disajikan dalam komik ini sangat dekat dengan masyarakat menengah ke bawah sebagai target utama pembaca karena mewakili keseharian mereka, sehingga dalam perkembangannya komik ini dapat diterima dan populer di masyarakat. Dalam komik ini, Tatang juga menyusupkan salam-salam dari para penggemarnya (kirim salam) di dalam salah satu halaman, hal ini dilakukan untuk menghargai para pembaca setia komiknya. Tatang Suhenra pun, selalu membalasnya dengan "Salam manis tidak akan habis, Salam sayang tidak akan hilang untuk semua pecinta karya saya" yang berada di halaman pembuka komik Gareng Petruk sebagai ciri khas.

Pilihan tokoh Gareng Petruk sebagai pembawa cerita, menunjukkan bahwa Tatang Suhenra ingin menyampaikan pesan bahwa ini adalah cerita dari sesama rakyat jelata, orang kebanyakan, dan masyarakat marginal yang ada di sekeliling pembaca dengan kehidupan yang penuh dengan lika liku masalah, selalu ada hal-hal yang bisa dinikmati dan disyukuri sebagai bagian dari karunia Tuhan. Petruk, Bagong, dan Gareng merupakan representasi sosok pembaca dari kelompok masyarakat Indonesia, yang memiliki kesulitan, kegundahan, dan menemukan masalah yang menghambat cita-cita atau mimpi mereka.

\section{b. Tema dan Plot Cerita}

Pada dasarnya, komik Gareng Petruk ini memiliki tiga jenis tema cerita utama yang selalu dikemas dengan humor-humor khas Tatang Suhenra. Ketiga jenis tema cerita utama tersebut adalah: 


\section{Horor}

Merupakan tema yang dominan dari cerita komik Gareng Petruk. Tema ini biasanya mengisahkan tentang Gareng atau Petruk yang bertemu berbagai sosok hantu pada saat ronda malam. Hantu yang ditampilkan sangat beragam, mulai dari hantu-hantu lokal seperti pocong, wewe gombel, atau penunggu sebuah tempat angker hingga hantu-hantu barat seperti vampir. Walau bertema horor, akan tetapi pembawaan cerita dan visual yang dibumbui humor yang menjadi sajian utama.

Tatang ingin mengubah pandangan masyarakat tentang sosok hantu yang menyeramkan menjadi lucu dengan menambahkan unsur humor di dalamnya. Tema komik ini tercipta dari kondisi sosial masyarakat Indonesia yang masih kental dan dekat dengan hal-hal mistis, sehingga tema ini menjadi tema yang dapat diterima oleh masyarakat Indonesia. Tatang melihat kecenderungan masyarakat Indonesia menyukai hal-hal gaib menjadi sebuah strategi yang untuk mendekatkan komiknya kepada target pembacanya.

\section{Romansa}

Selain unsur humor, unsur romansa dan erotisme juga terkadang terdapat dalam beberapa cerita pada tema horor, seperti kisah bertemu perempuan cantik yang digambarkan dengan perawakan sangat seksi, berstatus janda muda yang kesepian dan pada akhirnya berniat dijadikan pacar atau istri oleh Gareng ataupun Petruk. Tema romansa sebagai tema cerita utama pun merupakan salah satu tema yang banyak diolah oleh Tatang Suhenra. Tema ini muncul dari perkembangan komik roman yang juga sedang banyak disenangi oleh pembaca komik di Indonesia pada periode akhir 1970-an dan awal 1980-an. Komik ini biasanya menceritakan tentang kisah cinta Gareng atau Petruk dengan pacarnya yang mengalami berbagai persoalan seperti masalah ekonomi, status 
sosial yang membuat kisah cinta mereka terkadang harus kandas, namun pada akhirnya bisa kembali baik.
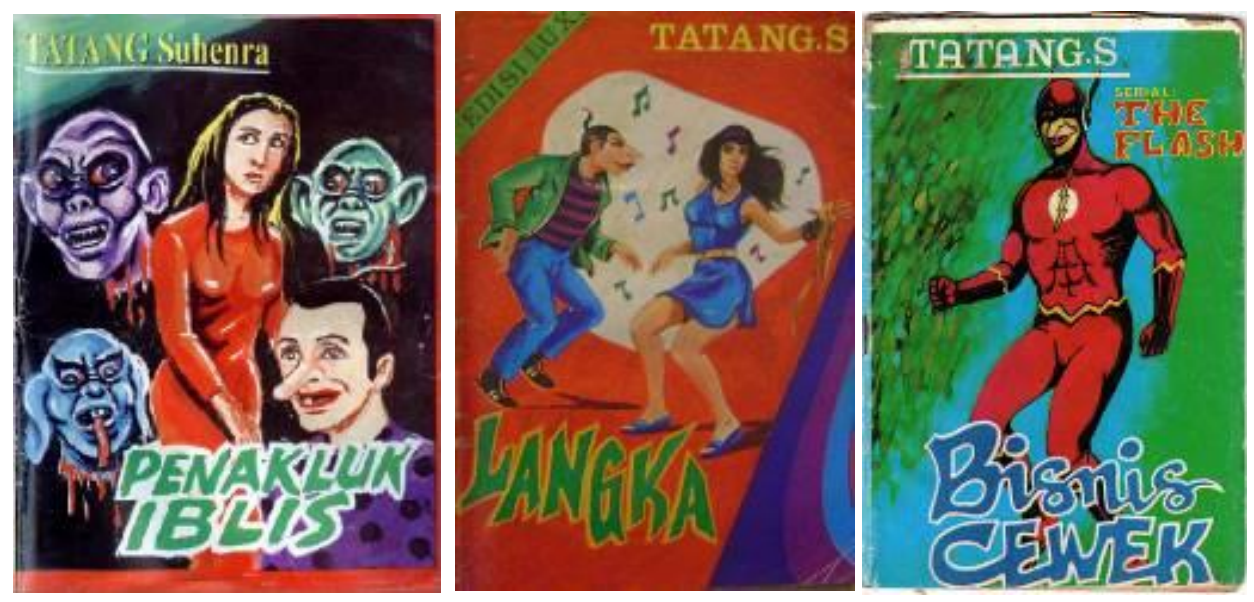

Gambar 4. Contoh komik karya Tatang Suhenra dengan tema horror (kiri), romansa (tengah), dan superhero (kanan) Sumber: Psikomedia, 2013.

Dalam komik ini, Tatang menampilkan konflik keseharian yang secara nyata sudah menjadi bagian dari masyarakat, khususnya masyarakat pinggiran kota. Akan tetapi, dalam komik ini banyak nilai-nilai kemanusiaan yang penting sebagai sebuah petuah bijak untuk menjalani kehidupan, walau terkadang dikemas oleh cerita humor. Tatang ingin menunjukkan pada masyarakat bahwa di setiap masalah yang membelit, pasti ada jalan keluar.

\section{Superhero atau Kepahlawanan}

Tema superhero yang muncul dalam komik Gareng Petruk mengacu pada trend komik superhero barat (khususnya komik terjemahan dari Amerika) yang beredar di pasar komik Indonesia pada tahun 1960-1980-an (Boneff, 2008). Tatang Suhenra mengadaptasi komik superhero tersebut dan mengubah image karakter superhero dengan genre komik Gareng Petruk yakni humor. Selain itu, Tatang Suhenra 
menambahkan nama desa tempat Gareng dan Petruk tinggal yakni desa tumaritis sebagai nama belakang dari superhero tersebut, seperti Batman Tumaritis, Superman Tumaritis, dan lain-lain.

Tatang ingin memberikan image lokal pada pahlawan adaptasi buatannya. Pahlawan yang ditampilkan bukan dari kalangan orang-orang khusus atau pilihan, melainkan sesama rakyat jelata dengan nasib sama seperti kebanyakan rakyat pinggiran. Dalam komik-komik superhero ini, konflik yang disajikan tidak terlalu rumit, cenderung berkaitan dengan keseharian yang biasa namun memiliki nilai kemanusiaan yang tinggi. Seperti halnya cerita Petruk yang menjadi superhero untuk melindungi pak guru dari serangan penjahat ketika hendak pergi mengajar di sekolah. Komik ini pun tidak terlepas dari unsur romansa atau erotisme yang dibawa Tatang. Salah satu cerita yang sering muncul yakni tentang Superhero Petruk yang harus menyelamatkan para wanita yang disandera oleh penjahat. Tokoh wanita selalu digambarkan dengan bentuk tubuh yang seksi dengan paras yang cantik.

\section{c. Setting atau latar}

Setting atau latar dalam setiap komik karya Tatang Suhenra selalu mengangkat konteks lokal, baik dalam hal latar tempat, latar waktu, maupun latar sosial. Oleh karena itu, dapat disimpulkan bahwa berdasarkan analisis visual pada aspek intrinsik komik, karya Tatang Suhenra memiliki karakter sebagai berikut, yaitu: tokoh yang merepresentasikan orang biasa atau warga masyarakat umum kota maupun pinggiran di Indonesia, mengangkat cerita keseharian dengan masalah serta mimpi dan cita-cita yang umum ditemui atau disampaikan oleh masyarakat perkotaan atau pinggir kota dengan strata sosial menengah ke bawah, serta didukung oleh latar yang umum ditemukan atau nama yang umum serta cukup familiar bagi masyarakat pembacanya. 

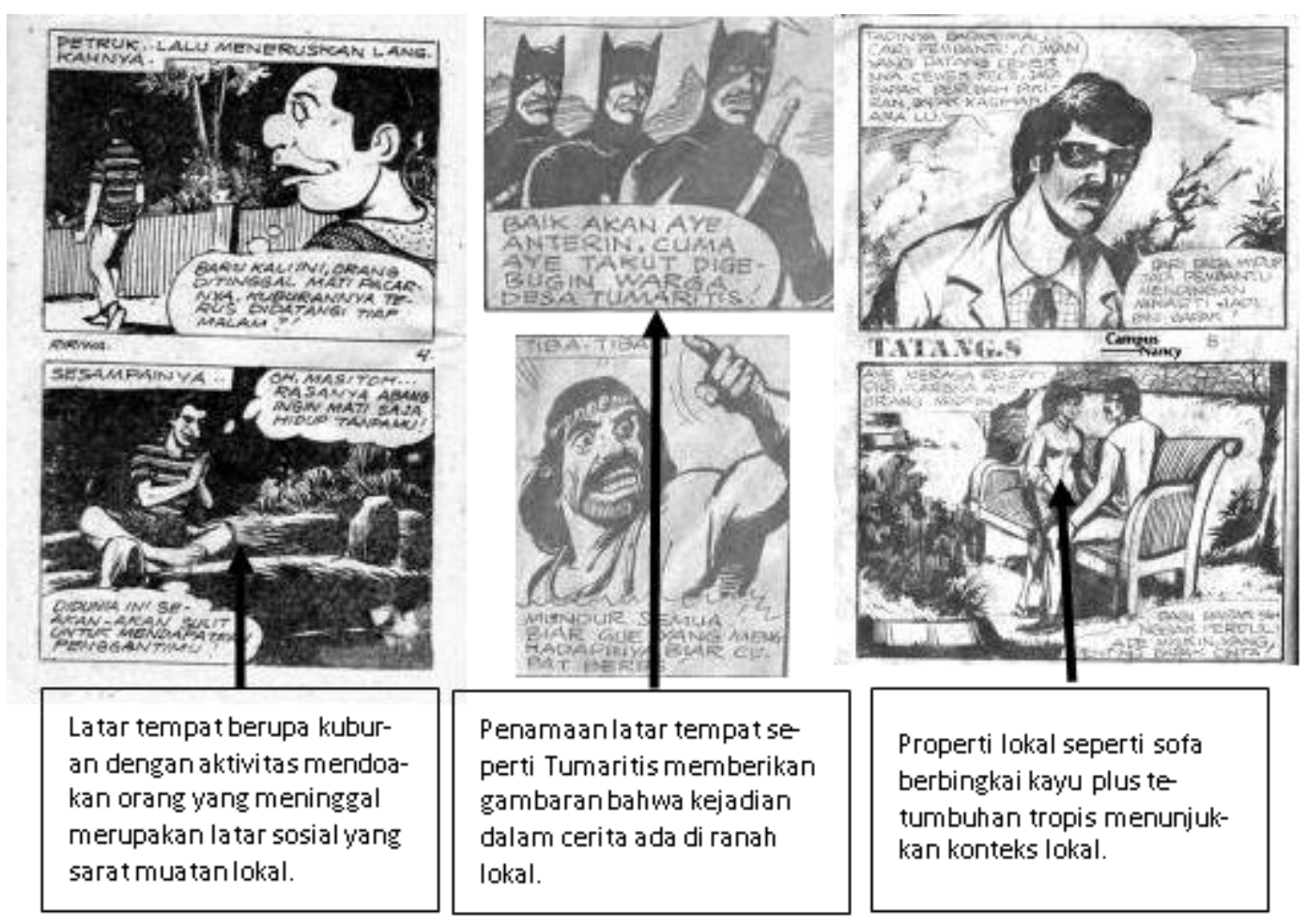

Gambar 5. Contoh latar dalam komik karya Tatang Suhenra dengan tema horror (kiri), romansa (tengah), dan superhero (kanan)

\section{Visual Storytelling Komik Karya Tatang Suhenra}

\section{a. Pemilihan Momen}

Pemilihan momen dan transisinya dalam komik, Tatang Suhenra intens menggunakan peralihan action to action dan subject to subject dalam ketiga genre komik karyanya. Khusus dalam komik genre kepahlawanan, porsi peralihan action to action, yaitu peralihan gambar antar panel dengan menekankan perubahan pada aksi atau gerak tokoh lebih banyak dibandingkan peralihan yang lain. Hal ini disebabkan oleh tema cerita ini lebih menekankan pada aspek aksi fisik tokoh cerita. Adapun dalam genre romansa dan horror, porsi peralihan subject to subject atau peralihan gambar antar panel dengan menekankan perubahan subjek cerita tanpa ada perubahan tempat atau scene lebih dominan frekuensinya. 


\section{b. Pemilihan Frame}

Semua halaman pada komik karya Tatang Suhenra memakai tipe dua frame (panel) dengan ukuran yang sama dalam satu halaman berukuran A5 (lihat Gambar 5). Komik dengan tipe visualisasi seperti ini umum digunakan dalam mayoritas komik yang diterbitkan pada periode 1960-1980-an (Boneff, 2008). Adapun sudut pandang yang digunakan adalah sudut pandang mata normal dengan jarak visualisasi antara close up sampai long shot (Gambar 6).
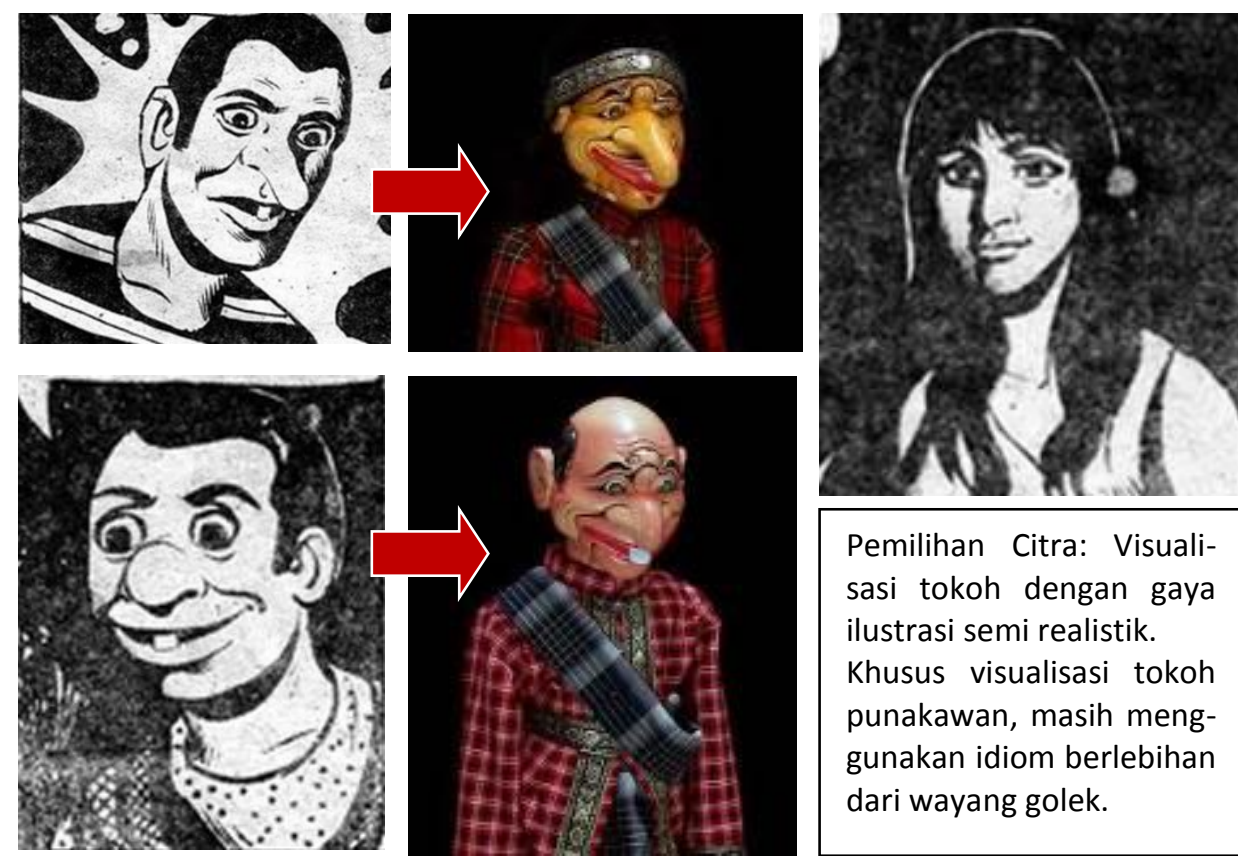

Pemilihan Citra: Visualisasi tokoh dengan gaya ilustrasi semi realistik. Khusus visualisasi tokoh punakawan, masih menggunakan idiom berlebihan dari wayang golek.

Gambar 6. Pemilihan citra tokoh yang semi realistik

\section{c. Pemilihan Citra}

Citra visual yang dimunculkan semi-realistik dengan penggunaan elemen visual khususnya pada muka yang berlebihan, khususnya pada tokoh punakawan. Aspek berlebihan atau hiperbola ini, mengikuti idiom atau gaya visual pada wayang, baik wayang kulit maupun wayang golek. Adapun tokoh lain selain punakawan, memunculkan figur yang semi-realistik dengan penyederhanaan pada elemen arsir dan pewarnaan yang menggunakan teknik ilustrasi arsir monokrom (hitam-putih) seperti terlihat pada Gambar 6. 
Adapun untuk citra latar tempat, menggunakan dua jenis visualisasi, yaitu latar yang menunjukkan tempat dengan elemen latar yang cukup detil dan lengkap, dan latar yang menunjukkan kedalaman ruang (depth of field) dalam ketiga genre komiknya.

\section{d. Pemilihan Kata}

Pemilihan kata dalam komik karya Tatang Suhenra menggunakan bahasa Indonesia dengan menyisipkan logat betawi sebagai intonasi maupun pengayaan dialog antar tokoh, khususnya tokoh Punakawan. Pemilihan logat betawi ketimbang logat sunda yang merupakan daerah asal Tatang Suhenra, lebih pada pertimbangan pemasaran dengan target pembaca yang mayoritas golongan menengah ke bawah yang tinggal di daerah urban dan pinggiran Jakarta.

\section{e. Pemilihan Alur}

Alur yang digunakan Tatang Suhenra dalam seluruh komiknya adalah alur lurus progresif. Alur ini dipilih karena pertimbangan jumlah halaman, dan jumlah panel serta panjang cerita yang dipilih, yaitu cerita singkat yang masuk dalam kategori slice of life. Dengan frame yang sederhana (dua panel/ frame per halaman). Dinamika cerita dibangun dari pemilihan momen dan pemilihan kata yang membangun alur naratif dengan bantuan interpretasi dari pembacanya untuk menghubungkan bagian cerita antar panel.

\section{KESIMPULAN}

Tema komik karya Tatang Suhenra terilhami dari kecenderungan tema media populer khususnya komik yang sedang berjaya pada tahun 1980-an, seperti superhero atau romansa. Tatang Suhenra menyesuaikan dengan target pembaca kelas menengah ke bawah, dengan tokoh Punakawan, untuk mewakili rakyat jelata dengan segudang masalah pada kehidupannya. Nuansa humor dipakai sebagai daya tarik dan hiburan bagi para pembaca. Pesan-pesan yang 
ingin Tatang Suhenra sampaikan melalui komiknya berkenaan dengan masalahmasalah masyarakat pinggiran, bahwa selalu ada jalan keluar apabila selalu berusaha dan berdoa.

Tatang Suhenra selalu mengangkat konteks lokal, baik secara trend gaya hidup dan ketertarikan masyarakat dalam menikmati konten dalam media layar kaca, tempat, waktu, bahkan tema cerita. Pemilihan tokoh cerita yang sedang trend dan khususnya punakawan pun merupakan pendekatan dengan pertimbangan konteks lokal bersifat trend konten dalam media audio visual khususnya layar kaca (televisi) di masyarakat.

Tatang Suhenra memandang dengan cerdas kondisi pasar pembaca komik, khususnya kelas menengah ke bawah yang tidak banyak dieksplorasi oleh penerbit besar sebagai lahan potensial untuk menerbitkan komiknya. Maka dengan kondisi demikian, dibuatlah komik Gareng-Petruk oleh Tatang yang telah disesuaikan dengan kondisi sosial-ekonomi masyarakat, baik dari segi cerita maupun harga komik itu sendiri.

\section{DAFTAR PUSTAKA}

Al Amin, 2015. Ini sosok Tatang S, komikus yang memopulerkan tokoh Petruk dkk [online] diunduh dari http://www.merdeka.com/peristiwa/ini-sosoktatang-s-komikus-yang-memopulerkan-tokoh-petruk-dkk.html [diakses pada 30 Desember 2015, pukul 19.30]

Bonneff, Marcel, 2008. Komik Indonesia. Jakarta, Kepustakaan Populer Gramedia.

Eisner, Will, 1996. Graphic Storytelling and Visual Narrative. W.W. Norton \& Co. MCCloud, Scott., 1993. Understanding Comics: The Invisible Art. New York, Harper Collins Publisher.

McCloud, Scott., 2005. Making Comics. New York, Harper Collins Publisher. 
Nurgiyantoro, Burhan, 2011. Teori Pengkajian Fiksi. Yogyakarta, Gadjah Mada University Press.

Permana, Ryan., 2012. Komik Silat Tatang S "Bayangan Setan" - 2347 - Sold! [online] diunduh dari http://goedangdjadoel.com/komik-silat-tatang-s\%E2\%80\%9Cbayangan-setan\%E2\%80\%9D-2347/ [diakses pada tanggal 21 April 2014, pukul 11.52]

Psikomedia, 2013. Mengingat kembali komik Petruk: Tatang S [online] diunduh dari http://foblog.psikomedia.com/read/Lounge/16285/mengingatkembali-komik-petruk-tatang-s/ [diakses pada 21 April 2014, pukul 13.00]

Sanggar Yudistira, 2013. Pembuatan Wayang Golek Murah [online] diunduh dari http://sanggaryudistira.blogspot.com/2013/09/pembuatan-wayang-golekmurah.html?m=1 [diakses pada 9 Mei 2014, pukul 11.25]

Sekedar Info, 2010. Sejarah Komik Gareng, Petruk, Semar, Bagong Karya Tatang S [online] diunduh dari http://parazitz.blogspot.co.id/2011/10/sejarahkomik-garengpetruksemar bagong.html [diakses pada tanggal 10 April 2014, pukul 11.15]

Suhenra, Tatang, 1986. Ririwa. Jakarta, Gultom Agency.

Vertikal Digital Indonesia, 2011. Nostalgia Bersama Tatang Suhenra [online] diunduh dari http://bandungreview.com/articles/view/645/nostalgiabersama-tatang-suhenra [diakses pada tanggal 10 April 2014, pukul 11.27] 